\title{
IMPLEMENTATION OF CASE MANAGEMENT FOR QUALITY IMPROVEMENT AT PURWOKERTO ISLAMIC HOSPITAL
}

\author{
Rini Indrian, Ikhlas Muhammad Jenie, Arlina Dewi
}

Masters Program in Hospital Management, Universitas Muhammadiyah Yogyakarta

\begin{abstract}
Background: Case management is a collaborative process of assessment, planning, facilitation, care coordination, evaluation, and advocacy for options and services to meet an individual's and family's comprehensive health needs through communication and available resources to promote quality, cost-effective outcomes. This study aimed to investigate the implementation of case management and its effects on quality of care at Purwokerto Islamic Hospital.

Subjects and Method: A qualitative study was conducted at Purwokerto Islamic Hospital, Purwokerto, Central Java, from December 2017 to March 2018. A sample of informants was selected for this study, consisting of 6 case managers and 15 patients with diabetes mellitus. The dependent variable was service quality, including communication, collaboration, coordination, patient satisfaction, and care giver satisfaction. The independent variable was implementtation of case management. The data were collected by questionnaire, in-depth interview, observation, and document review.

Results: Satisfaction among health professions (doctors, nurses, other health providers), was higher after implementation of case management than before. Likewise, patient satisfaction, particularly inpatient, was higher after case management than before.

Conclusion: Case management has been implemented at Purwokerto Islamic Hospital, and has improved the quality of health service, and has increased patient satisfaction.
\end{abstract}

Keywords: case management, service quality, patient satisfaction

\section{Correspondence:}

Rini Indrian. Masters Program in Hospital Management, Universitas Muhammadiyah Yogyakarta, Jl. Lingkar Selatan, Tamantirto, Kasihan, Bantul, Yogyakarta. Email: nersindri@gmail.com. Mobile: 085747777361 